\title{
Investigation of local anesthetic and antimycobacterial activity of Ottonia martiana Miq. (Piperaceae)
}

\section{MIRIAM M. CUNICO ${ }^{1}$, HERBERT A. TREBIEN ${ }^{2}$, FÁBIO C. GALETTI ${ }^{3}$, OBDULIO G. MIGUEL $^{4}$, MARILIS D. MIGUEL ${ }^{4}$, CELSO G. AUER ${ }^{5}$, CÉLIO L. SILVA $^{3}$ and ANA OLÍVIA DE SOUZA ${ }^{6}$}

\author{
${ }^{1}$ Laboratório de Inventário Florestal, Departamento de Ciências Florestais, Universidade Federal \\ do Paraná, Av. Prefeito Lothário Meissner, 632, 80210-170 Curitiba, PR, Brasil \\ ${ }^{2}$ Laboratório de Fisiologia e Farmacologia do SNC, Departamento de Farmacologia, Universidade Federal \\ do Paraná, Av. Alcides Vieira Arcoverde, s/n, Jardim das Américas, 81531-990 Curitiba, PR, Brasil \\ ${ }^{3}$ Faculdade de Medicina de Ribeirão Preto, Universidade de São Paulo, Av. Bandeirantes, 3900, 14049-900 Ribeirão Preto, SP, Brasil \\ ${ }^{4}$ Departamento de Farmácia, Universidade Federal do Paraná, Av. Prefeito Lothário Meissner, 632, 80210-170 Curitiba, PR, Brasil \\ ${ }^{5}$ Laboratório de Patologia Florestal, Embrapa Florestas, Estrada da Ribeira, Km 111, s/n, 83411-000 Colombo, PR, Brasil \\ ${ }^{6}$ Laboratório de Bioquímica e Biofísica, Instituto Butantan, Av. Vital Brasil, 1500, 05503-900 São Paulo, SP, Brasil
}

Manuscript received on February 21, 2014; accepted for publication on January 16, 2015

\begin{abstract}
Ottonia martiana is a plant popularly known in Brazil by the use for toothache. Ethanolic extract (EE), hexane fraction (HF), dichloromethane fraction (DF) and piperovatine obtained from O. martiana were assayed in vitro and in vivo. The acute toxicity of $\mathrm{EE}$ was determined, and $\mathrm{LD}_{50}$ values of 164.5 and $65.0 \mathrm{mg} /$ $\mathrm{kg}$ by the oral and intraperitoneal routes, respectively, indicated a high toxicity for EE in vivo, explaining its popular use by topical administration only. A local anesthetic-like effect of EE and its fractions was observed in experimental models using pain induction, and such effect involved an analgesic action. The antimycobacterial activity of EE, HF, DF and piperovatine was evaluated against Mycobacterium tuberculosis H37Rv ATCC 27924. EE, HF, DF, and piperovatine showed a potential antimycobacterial effect with MICs of 16.0, 62.0, 62.0 and $8.0 \mu \mathrm{g} / \mathrm{mL}$, respectively. Piperovatine was more effective than the $\mathrm{EE}$ or the other fractions. The selectivity index $\left(\mathrm{SI}=\mathrm{IC}_{50} / \mathrm{MIC}\right)$ values calculated for $\mathrm{EE}, \mathrm{HF}, \mathrm{DF}$ and piperovatine based on the MICs and the cytotoxicity against $\mathrm{J} 774$ macrophages ( $\mathrm{IC}_{50}$ by MTT assay) revealed values of $6.43,2.34,1.5$ and 9.66 , respectively.
\end{abstract}

Key words: analgesic, anesthetic, antimycobacterial, Ottonia martiana, Piperaceae, piperovatine.

\section{INTRODUCTION}

The use of natural products, particularly those obtained or derived from plants, is an integral part of mankind's history, where they have played a role

Correspondence to: Miriam Machado Cunico

E-mail: miriammcunico@gmail.com in the treatment of diseases and even in improving quality of life.

Plants offer an inexpensive alternative treatment, which can be exploited by indigenous people who cannot afford or purchase commercially available drugs. The World Health Organization estimated that about $80 \%$ of the population in 
developing nations relies on plant-based traditional medicine for primary health care (WHO 2002). It is estimated that there are at least 5,000,000 species of plants around the world and that the 25 global biodiversity hotspots support nearly 50,000 endemic species (Elmqvist 1997).

Only 10-15\% of terrestrial biodiversity, especially vascular plants have already been already explored phytochemically for medicinal applications (Kinghorn and Balandrin 1993), and the main categories of plant-derived drugs are terpenes, glycosides, amides, and others (Wilkinson et al. 2002).

The screening of plants in order to find secondary metabolites, and the development of drugs are very hard tasks which demand considerable effort starting from botanical identification, collection, extraction, isolation, purification and compound identification to pharmacological and other studies. Even though the potential antimicrobial activity of plant extracts has already been well demonstrated, few studies on bacteria of clinical relevance in dentistry have been conducted in Brazil.

Although scientific advances have been made, Brazilian people are still affected by caries and periodontal disease. Microorganisms such as Streptococcus mutans from human oral microbiota are related to the formation of dental plaques and are determinants in the development and progression of caries and periodontal disease. Measures for their prevention and control must be intensified (Groppo et al. 2002). In this regard, acquired antibiotic resistance in some microorganisms has led to the alternative search of potential antimicrobial substances in plants (Al-Bayati and Sulaiman 2008, Ccahuana-Vasquez et al. 2007, Sarac and Ugur 2007).

Among some plant species popularly used in diseases of the oral cavity is Ottonia martiana Miq. (Piperaceae), a local shrub plant of the Brazilian Atlantic Forest (Cunico et al. 2006). In the South and Southeast regions of Brazil, it is popularly known as "jaborandi," "jaguarandi" and "taburutá"
(Guimarães et al. 1978), and by the natives of the coast of the state of Paraná, O. martiana is known as "anestésia" (anesthesia). The roots and aerial parts of $O$. martiana in ethanolic preparations are largely employed in the treatment of dental problems, due to its pain relieving action in the oral cavity (Cunico et al. 2003).

Phytochemical investigations of the roots and aerial parts of $O$. martiana resulted in the isolation of the isobutylamides piperlonguminine, isopiperlonguminine and piperovatine, bioactive substances of medical interest. Seventy-seven compounds were identified as components of three essential oils extracted from leaves, fruits and roots of this plant (Cunico et al. 2007). These chemical compounds were previously isolated from a number of closely related Piperaceae species (Giesbrecht et al. 1981, Makapugay et al. 1983, McFerren and Rodrigues 1998, Price and Pinder 1970, Pring 1982, Costa and Mors 1981).

Recent phytochemical investigations of the Piperaceae species have traced the piscicidal, oral "local anesthetic", and saliva-inducing (sialogogic) properties of piperovatine (McFerren et al. 2002) and insecticide potential of piperlonguminine (Sáez et al. 1998).

Biological studies with the crude extracts of roots and aerial parts of $O$. martiana showed antimicrobial activity against both human and plant pathogens (Cunico et al. 2006, 2007). However, to date, there are no records of related pharmacological studies.

Although the antibacterial activity of $O$. martiana has already been demonstrated against some microorganisms, no study has been performed on bacteria associated with conditions of clinical relevance in dentistry or on Mycobacterium tuberculosis, the main pathogen responsible for tuberculosis. Therefore, the main aim of the present study was to investigate the potential of local anesthetic and antimycobacterial activities of Ottonia martiana Miq. extracts. Pharmacological activity in terms of acute toxicity was also evaluated 
since there is no previous study regarding the toxicological effect of this plant.

\section{MATERIALS AND METHODS}

\section{REAGENTS AND ANIMALS}

All reagents were of analytical grade. Swiss mice (Mus muscullus) (25 $\pm 5 \mathrm{~g})$, guinea pigs (Cavia porcellus) $(250 \pm 50 \mathrm{~g})$, and albino rabbits (Oryctolagus cuniculus) $(3 \pm 1 \mathrm{~kg})$ were used. Animals were housed under a $12 \mathrm{~h}$ light/ dark cycle in a temperature-controlled room with free access to water and food. The study was approved by the Research Ethics Committee of the Universidade Federal do Paraná, Process number 23075.039511/2006-47, and the experimental protocols were approved by the Brazilian Committee of Animals (\# 193/06) and in accordance with the recommended guidelines.

\section{PLANT MATERIAL AND PREPARATION OF EXTRACT AND FRACTIONS}

Roots and aerial parts of $O$. martiana were collected in the state of Paraná, Southern Brazil, in April 2002. The plant was identified by Dr. Gerdt Hatschbach of the Botany Museum (MBM) of Curitiba City Council, state of Paraná, and the voucher specimens were deposited at the MBM Herbarium under number 259,057.

Dried, powdered roots and aerial parts of $O$. martiana $(700 \mathrm{~g})$ were exhaustively extracted by triple maceration with $95 \%$ ethanol for seven days at room temperature. Removal of the solvent from the extract by evaporation under reduced pressure $\left(40{ }^{\circ} \mathrm{C}\right)$ yielded a dark viscous product $(32.9 \mathrm{mg} /$ $\mathrm{mL}$ ). This ethanolic extract (EE) was stored at $4{ }^{\circ} \mathrm{C}$ and was diluted with saline prior to any preliminary pharmacological test. A part of EE was partitioned $(\mathrm{L} / \mathrm{L})$ with hexane $(\mathrm{H})$, dichloromethane (D), ethyl acetate (AE) and methanol (M), as previously described by Cunico et al. (2006). EE and the fractions obtained (HF - $0.86 \mathrm{~g}, \mathrm{DF}-0.42 \mathrm{~g}$, AEF - $0.1 \mathrm{~g}, \mathrm{MF}-0.5 \mathrm{~g}$ ) were submitted to bioassays.
Isobutylamide piperovatine was obtained as previously described (Cunico et al. 2006).

ACUTE TOXICITY TEST $\left(\mathrm{LD}_{50}\right)$

Mice of both sexes $(n=10)$ were fasted overnight, and the crude extract (EE dissolved in $95 \%$ saline with ethanol $-4 \% \mathrm{v} / \mathrm{v}$ ) plus $1 \%$ Tween 80 was administered by oral gavage (100, 150 and $200 \mathrm{mg} /$ $\mathrm{kg}$ ) and intraperitoneally (40, 60 and $80 \mathrm{mg} / \mathrm{kg})$. Mice were observed daily for 14 days following treatment. The number of dead mice within the study period was recorded for each group, and the lethal dose $-\mathrm{LD}_{50}$ - was calculated by the probit method using the mortality percentage and the logarithm of the EE concentrations tested. The plots were analyzed by linear regression (Litchfield and Wilcoxon 1949).

\section{SURFACE ANESTHESIA IN THE RABBIT CORNEA}

The procedure was performed according to Vogel (2002). Albino rabbits $(2-4 \mathrm{~kg})$ of both sexes $(n=5)$ were placed in a confinement box, and their eyelashes were cut. The cornea was touched 10 times with a nylon fiber and the number of reflexes was recorded. Afterwards, the eyes were opened and EE $(2 \mathrm{mg} / \mathrm{mL})$ was instilled into the conjunctiva. Controls were performed with lidocaine $(2 \%)$ or saline with ethanol (4\% v/v) and Tween 80 (1 $\%$ ). First, $0.5 \mathrm{~mL}$ of each solution was added, and after $30 \mathrm{sec}$, the procedure was repeated with an additional $0.5 \mathrm{~mL}$ making a total volume of $1 \mathrm{~mL}$. Next, the eyes were touched with the nylon fiber 10 times every $5 \mathrm{~min}$ for $1 \mathrm{~h}$, and the palpebral reflexes were counted.

INFILTRATION ANESTHESIA IN GUINEA PIG WHEAL

An intradermic anesthesia test was performed as previously published by Rates et al. (1997) with modifications. Guinea pigs (Cavia porcellus) of 250 up to $300 \mathrm{~g}$ were separated (male from female), and the dorsal hair was shaved $24 \mathrm{~h}$ before the experiment (Bülbring and Wajda 1945). 
Additionally animals were allowed to rest one day to eliminate any sign of skin irritation. EE (20 $\mathrm{mg})$, HF (6 mg), DF (10 mg), EAF (1.5 mg) and MF (5 mg) were intradermically administered in 3 different areas (2-3 cm of diameter) on the back of each animal. Lidocaine (2\%) and saline (with ethanol $4 \%$ plus Tween $80(1 \%)$ were used as controls. EE, the fractions (HF, DF, EAF and MF) and lidocaine were dissolved in saline (as described above).

The formed wheals were outlined 5 min after the treatments. The sensitivity of each area was determined by the number of contractions after six light stimuli with a needle in random places every 5 $\min$ for $30 \mathrm{~min}$. The score for contractions for each wheal was determined for a total of 36 stimuli.

\section{ANTIMYCOBACTERIAL ACTIVITY}

The antimycobacterial activity of EE, fractions (HF and DF) and piperovatine was evaluated against Mycobacterium tuberculosis H37Rv ATCC 27924 using microplate assay (Palomino et al. 2002). The samples were assayed in concentrations ranging from 0.06 up to $125 \mu \mathrm{g} / \mathrm{mL}$ in three independent experiments, and the minimal inhibitory concentrations (MICs) were determined using the rezazurin dye. The blue color represents inhibition of at least $90 \%$ and rifampicin was used as the positive control at concentrations less than $64 \mu \mathrm{M}$. The visual minimal inhibitory concentration (MIC) was defined as the lowest that prevented a color change from blue to pink due to the inhibition of mycobacterial growth.

\section{CITOTOXICITY ASSAY ON J774 MACROPHAGES}

Cytotoxicity of EE, fractions HF and DF, and piperovatine expressed as loss of cell viability was determined using the 3-(4,5-dimethylthiazol2-yl)-2,5-diphenyl tetrazolium bromide (MTT) reduction method in $\mathrm{J} 774$ macrophages (Denizot and Lang 1986). J774 macrophages were grown as monolayers in RPMI 1640 medium supplemented with $10 \%$ heat inactivated fetal bovine serum(FBS),
$100 \mathrm{IU} / \mathrm{mL}$ penicillin and $100 \mu \mathrm{g} / \mathrm{mL}$ streptomycin in a humidified incubator with $5 \% \mathrm{CO}_{2}$ in air at $37^{\circ} \mathrm{C}$. Cells were plated in $96-$ well plates at a concentration of $2 \times 10^{6}$ cells $/ \mathrm{mL}$. The medium was removed $12 \mathrm{~h}$ after seeding and replaced with a medium containing EE at concentrations from 0 to $1,000 \mu \mathrm{g} / \mathrm{mL}$ and the other samples from 0 to 200 $\mu \mathrm{g} / \mathrm{mL}$. Cells were exposed for $24 \mathrm{~h}$ to test medium with or without (control) the drugs.

Selectivity index (SI) of the test samples were calculated using formula $\mathrm{SI}=\mathrm{IC}_{50} / \mathrm{MIC}$, taking into account the concentrations that reduced cell viability in $\mathrm{J} 774$ macrophages by $50 \%\left(\mathrm{IC}_{50}\right)$ and the MIC against M. tuberculosis H37Rv.

\section{STATISTICAL ANALYSES}

Data were subjected to analysis of variance (ANOVA) followed by Tukey's post hoc test, and $\mathrm{p}<0.05$ was considered statistically significant. The variable evaluated in the response to the test stimulus with a needle did not show normal distribution, and thus, the Kruskal-Wallis test was performed followed by the Mann-Whitney test for comparisons between different treatments. Assays done over time were compared by the Friedman test followed by the Wilcoxon test.

\section{RESULTS AND DISCUSSION}

\section{ACUTE TOXICITY TEST $\left(\mathrm{LD}_{50}\right)$}

Animals were treated with crude EE of $O$. martiana at 40, 60 and $80 \mathrm{mg} / \mathrm{kg}$ i.p. and 100, 150 and 200 $\mathrm{mg} / \mathrm{kg}$ p.o. No deaths were observed for the lowest doses by the i.p. and oral routes (40 and $100 \mathrm{mg}$ / $\mathrm{kg}$ ). Thirty and $44.4 \%$ of the animals died with intermediate doses by the i.p. and oral routes, respectively. Nearly all animals died with the highest doses ( 90 and $80 \%$ for $80 \mathrm{mg} / \mathrm{kg}$ i.p and 200 $\mathrm{mg} / \mathrm{kg}$ p.o., respectively). The $\mathrm{LD}_{50}$ was 65 (C.I. 56-75) and 164.5 (C.I. 148-183) $\mathrm{mg} / \mathrm{kg}$ by the i.p. and oral routes, respectively (Fig. 1). These results suggest that there was probably a higher absorption of EE by the i.p. route, which was expected. 


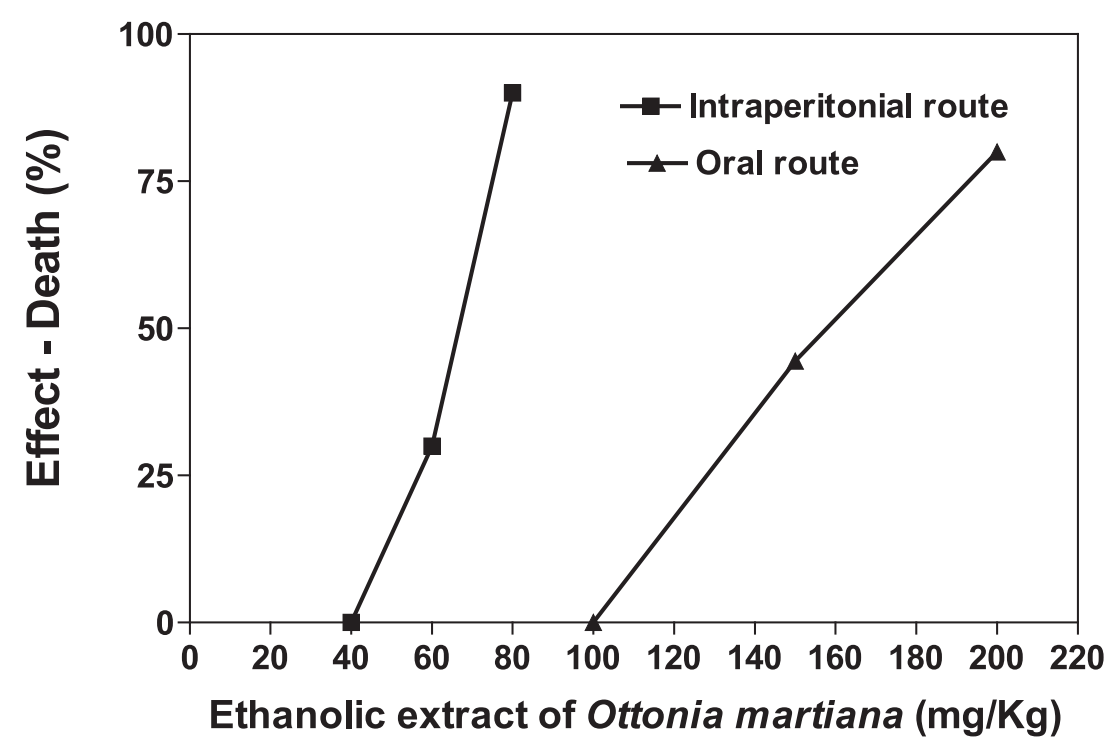

Figure 1 - Acute toxicity of ethanolic extract of Ottonia martiana by oral and intraperitoneal (i.p) administration. LD $_{50} 65 \mathrm{mg} / \mathrm{kg}, \mathrm{CI} 56-75 \mathrm{mg} / \mathrm{kg}$ i.p. and 164.5, CI $148-183 \mathrm{mg} / \mathrm{kg}$ p.o.

Animals submitted to the acute toxicity assay through the i.p. administration of EE showed abdominal contractions and vocalization related to pain. Animals also showed stereotypic behaviors such as sniffing, licking paws and repeated scratching of the nose, intense salivation, erection of the tail (Straub assay positive), tremors, difficulty in breathing, reduced deambulation and back tone, such as reduced ability to hold back. Animals died after interspersed convulsions and intense sedation.

EE showed high toxicity attributed to the action of the compounds isobutylamides piperovatine, isopiperlonguminine and piperlonguminine. There was probably a synergistic effect (Souza et al. 2003).

\section{SURFACE ANESTHESIA IN THE CORNEA RABBIT}

In the saline-treated groups, each stimulus was accompanied by blinking, where lidocaine (20 $\mathrm{mg}$ ) practically abolished the corneal reflex $5 \mathrm{~min}$ after instillation, and this effect disappeared in approximately $60 \mathrm{~min}$. EE at doses of 2 to $20 \mathrm{mg}$ did not significantly change the eye lid reflexes (10 \pm 1 reflexes) during the observation time of $1 \mathrm{~h}$.
These data suggest that the crude extract has no anesthetic effect (Fig. 2).

INFILTRATION ANESTHESIA IN GUINEA PIG WHEAL

In this study, the cutaneous reflexes induced by needle stimulation on guinea pigs were inhibited by $\mathrm{EE}$ at $20 \mathrm{mg}$ in comparison with the group treated with saline (Fig. 3).

The inhibitory effect of EE was similar to that of lidocaine $(2 \%)$, with a maximal effect 5 min after injection followed by gradual decline in effect. The number of twitches was reduced and statistically different from the saline group $(p<0.05)$. During this time, the same results were observed for the group treated with lidocaine. However, during the first $5 \mathrm{~min}$ of the treatment, lidocaine was more effective than EE in reducing the cutaneous reflexes. Although these results suggest an anesthetic effect of EE, this could also be considered. The amide piperovatine is present in the extract and is structurally related to local anesthetics such as lidocaine. On the other hand, this compound has an effect on voltage-dependent sodium channels, stimulating their opening, with no blocking effect 28 (McFerren et al. 2002). 


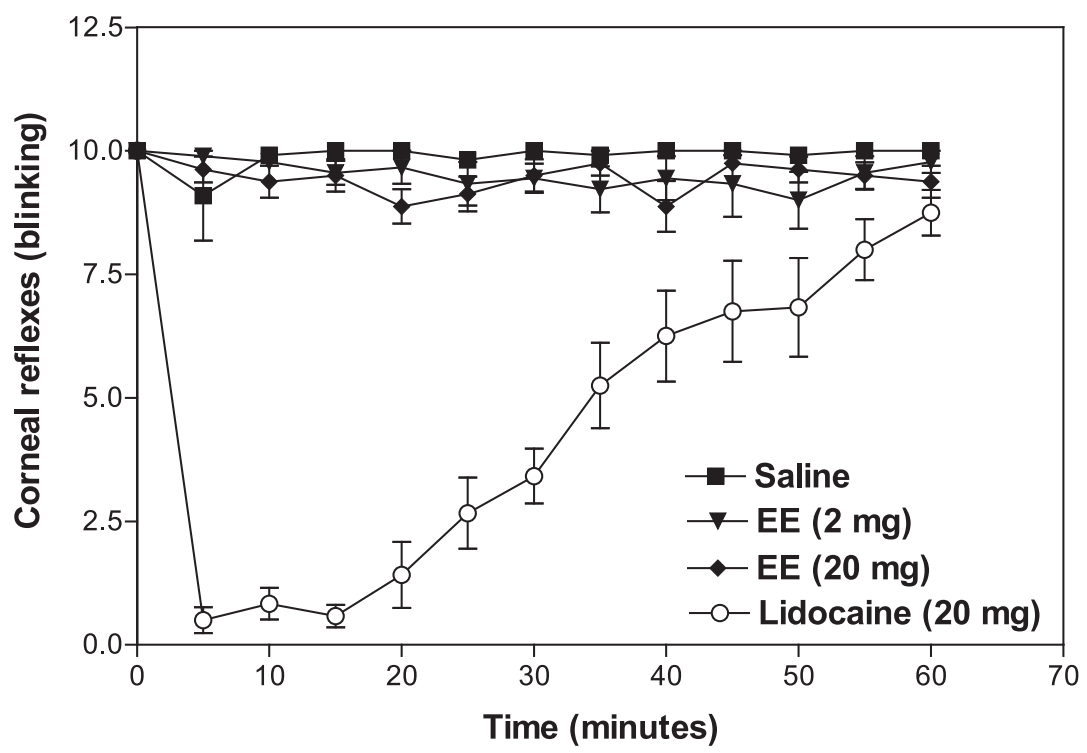

Figure 2 - Surface anesthesia on the cornea of rabbits. Instillation of lidocaine (2\%) completely abolishes the corneal reflex $(\mathrm{p}<0.05)$ in rabbits $(\mathrm{n}=8-11$ animals/group $) 5$ minutes after application, and this effect is reversed in 1 hour. The ethanolic extract of Ottonia martiana, 2 or $20 \mathrm{mg}$, and saline did not inhibit blinking.

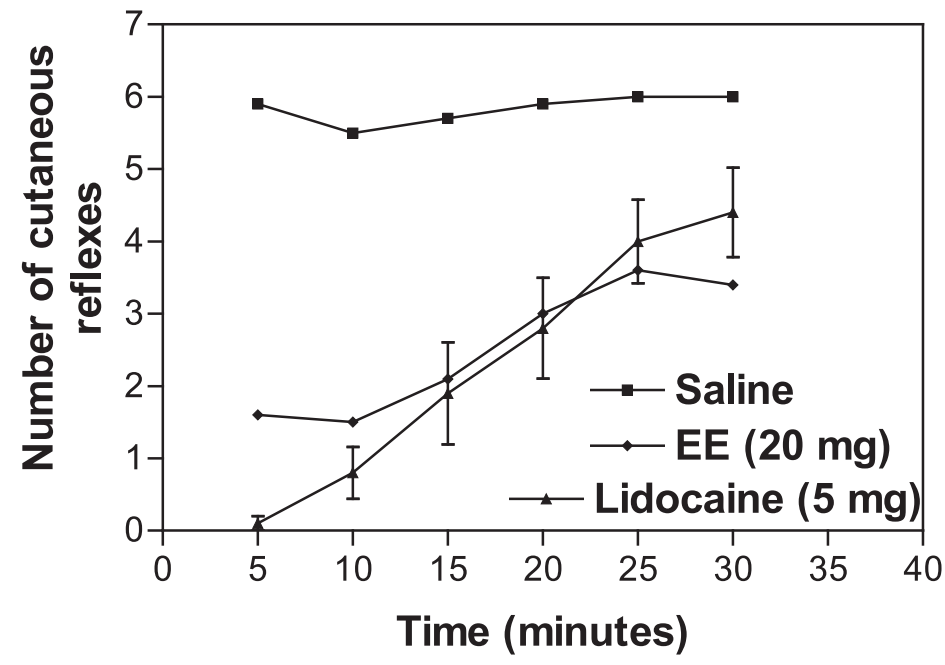

Figure 3 - Infiltration anesthesia in guinea pig wheal test. Effect of the ethanolic extract (EE) of Ottonia martiana $(20 \mathrm{mg}, \mathrm{n}=10)$ on cutaneous reflexes in guinea pig wheal test. Inhibition was statistically significant compared to saline control $(\mathrm{p}<0.05)$, but similar to lidocaine $(2 \%)$.

The intracellular increase in calcium is also an indication of the release of neurotransmitters due to the action of piperovatine, which also explains the sialagogue effect of this compound, where neurons can release acetylcholine, stimulating salivation. It is important to highlight that piperovatine is also structurally related to the analgesic compound capsaicin and could have similar effects through the stimulation of nociceptive afferent neurons by binding to vanilloid receptors. This receptor is a cation channel activated by ligands and permeable to sodium and calcium ions. Furthermore, 
capsaicin is an agonist of this receptor, inducing an increase in calcium influx (Rang et al. 2001) and releasing several neuropeptides involved in pain transmission, mainly the tachykinins (substance $\mathrm{P}$, neurokinins A and B) (Sakurada et al. 1992). The initial action of capsaicin is stimulatory and can be followed by desensitization of nerve endings with substance P depletion and elimination of pain.
Taking into account the effects of EE of $O$. martiana observed in this study and its high toxicity, further investigation of isolated compounds of this plant is warranted. To identify the fraction(s) responsible for this analgesic-like effect, the fractions MF, EAF, DF and HF were prepared and tested by infiltration anesthesia in the guinea pig wheal model (Fig. 4).

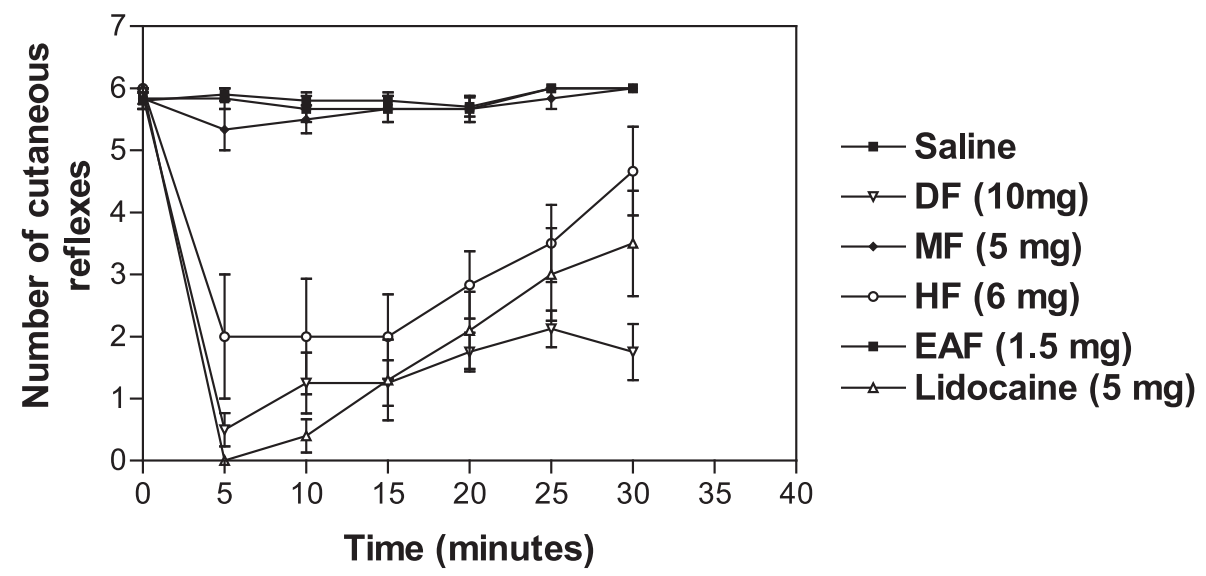

Figure 4 - Effects of Ottonia martiana fractions on cutaneous reflexes in guinea pig wheal test. Animals were treated with fractions (F): MF (methanolic), EAE (ethyl acetate), DF (dichloromethane) and HF (hexane) for $30 \mathrm{~min}$. The control groups were treated with saline (negative) or lidocaine (positive).

The cutaneous reflexes were not inhibited by the most polar fractions, MF and EAF. However, the fractions DF and HF inhibited the reflexes, and this effect was statistically significant in comparison with the control group treated with saline $(\mathrm{p}<0.05)$.

Although biologically effective in treating toothache, the toxicity of $O$. martiana EE and its bioactive fraction is a limiting factor in considering their systemic use; however, a local anesthetic/ analgesic-like effect could be hypothesized. To understand this effect and elucidate the mechanism of action, new models or assays must be evaluated taking into account vanilloid and purinergic receptors. Isolated compounds must also be considered to determine if there is any synergistic effect of the compounds present in the crude extract. It has been reported that EE of O. martiana contains b-caryophyllene, a sesquiterpene known as a local anesthetic (Cunico et al. 2007, Ghelardini et al. 2001).

\section{ANTIMYCOBACTERIAL ACTIVITY AND CITOTOXICITY ON J774 MACROPHAGES}

EE showed potential antimycobacterial activity against M. tuberculosis H37Rv ATCC 27924 with a MIC of $16 \mu \mathrm{g} / \mathrm{mL}$. HF and DF showed activity with a MIC of $62 \mu \mathrm{g} / \mathrm{mL}$. Piperovatine was more effective than EE and fractions evaluated with a MIC of $8 \mu \mathrm{g} / \mathrm{mL}$. The control rifampicin showed MIC of $0.02 \mu \mathrm{g} / \mathrm{mL}(0.024 \mu \mathrm{M})$.

With regard to cytotoxicity, $\mathrm{IC}_{50}$ values were 103.0, 145.0, 93.0 and $77.05 \mu \mathrm{g} / \mathrm{mL}$ for EE, HF, DF and piperovatine, respectively. The selectivity index values were calculated for EE, HF, DF and piperovatine based on the MIC and cytotoxicity $\left(\mathrm{IC}_{50}\right)$ against $\mathrm{J} 774$ macrophages and were 6.43, 
2.34, 1.5 and 9.66, respectively. Although the SI values are not high enough to ensure specificity of the test samples with respect to $M$. tuberculosis versus the host, it is important to continue studies in order to find new derivatives or analogues with higher antimycobacterial activity and lower cytotoxicity.

EE of $O$. martiana showed $\mathrm{LD}_{50}$ higher (164.5 and $65 \mathrm{mg} / \mathrm{kg}$ by oral and i.p. route, respectively) than that of the anesthetic lidocaine (292.0 and $105.0 \mathrm{mg} / \mathrm{kg}$ by oral and i.p. route, respectively). Due to its high in vivo toxicity this sample could be investigated for local or topical use.

The inhibition of cutaneous reflexes in guinea pigs suggests an analgesic effect of EE, since in this model there is induction of pain through needle stimulation. This activity can be related to the opening of sodium channels due to piperovatine present in this crude extract, which could contribute to the release of endogenous compounds and the inhibition of the analgesic stimulus.

Although this hypothesis is possible, the anesthetic effect cannot be discarded since this extract can act through vanilloid and canabinoid receptors, also contributing to the analgesic effects. The intradermic pharmacological assay allows the detection of the activity of the fractions HF and DF from EE of $O$. martiana.

These results indicate an effective in vitro activity of $O$. martiana extract and its fractions, including piperovatine, on the inhibition of bacterial growth and encourage further studies for its application in bacteria-associated disease of the oral cavity.

The mechanisms of action of EE of $O$. martiana were not elucidated, but the biological activities observed in vitro and in vivo are in accordance with the popular topical use of this plant species. However, further studies on the relationship of both the identification and the structure-activity of these antibacterial substances remain to be performed. In addition, pharmacological investigations (such as testing with different analgesia models, evaluation of anti-inflammatory activity and analysis of the urinary electrolyte profile, etc.), and bioactivityguided phytochemical studies are required to determine the actual active constituents.

\section{RESUMO}

Ottonia martiana é uma planta popularmente conhecida no Brasil pelo uso para dor de dente. Extrato etanólico (EE), fração hexano (HF), fração diclorometano (DF) e piperovatina, obtidos de $O$. martiana, foram ensaiados in vitro e in vivo. A toxicidade aguda de $\mathrm{EE}$ foi determinada e valores de $\mathrm{LD}_{50} 164,5$ e $65,0 \mathrm{mg} / \mathrm{kg}$ pelas rotas oral e intraperitoneal, respectivamente, indicaram alta toxicidade para EE in vivo, explicando seu uso popular somente pormeio da administração tópica. Um efeito local similar ao anestésico do EE e das frações foi observado em modelos experimentais utilizando indução de dor e tal efeito envolveu uma ação analgésica. A atividade antimicobacteriana de EE, HF, DF e piperovatina foi avaliada contra Mycobacterium tuberculosis H37Rv ATCC 27924. EE, HF, DF e piperovatina mostraram um efeito antimicobacteriano potencial com MICs de 16,0, $62,0,62,0$ e $8,0 \mu \mathrm{g} / \mathrm{mL}$, respectivamente. Piperovatina foi mais efetiva que $\mathrm{EE}$ e as outras frações. Os valores do índice de seletividade ( $\mathrm{SI}=\mathrm{IC}_{50} / \mathrm{MIC}$ ) calculados para EE, HF, DF e piperovatina, baseados em MICs e na citotoxicidade contra $\mathrm{J} 774$ macrófagos $\left(\mathrm{IC}_{50}\right.$ pelo teste MTT), revelaram valores de 6,43, 2,34, 1,5 e 9,66, respectivamente.

Palavras-chave: analgésico, anestético, antimicobacteriano, Ottonia martiana, Piperaceae, piperovatina.

\section{ACKNOWLEDGMENTS}

The authors are grateful to Conselho Nacional de Desenvolvimento Científico e Tecnológico (CNPq) for providing the research grant and fellowships. Dr. A. Leyva helped with English editing of the manuscript.

\section{REFERENCES}

AL-BAYATI FA AND SUlAimAN KD. 2008. In vitro antimicrobial activity of Salvadora persica L. extracts against some isolated oral pathogens in Iraq. Turk J Biol 32: $57-62$. 
BÜLBRING E AND WAJDA I. 1945. Biological comparison of local anesthetics. J Pharmacol Exp Ther 85: 78-84.

CCAHUAnA-VASQuez RA, SAntos SSF, KogA-ITO CY AND JORGE AOC. 2007. Antimicrobial activity of Uncaria tomentosa against oral human pathogens. Braz Oral Res 21: 46-50.

COSTA SS AND MORS WB. 1981. Amides of Ottonia corcovadensis. Phytochemistry 20: 1305-1307.

CUNiCO MM, Dias JG, Miguel MD, Miguel OG, AUER CG, CÔCCO LC, LOPES AR, YAMAMOTO CI AND DELLE MONACHE F. 2006. Antimicrobial and allelopathic potential of the amides isolated from the roots of Ottonia martiana Miq., Piperaceae. Quim Nova 29: 746-749.

CUNICO MM, LOPES AR, CÔCCO LC, YAMAMOTO CI, Plocharski RCB, Miguel MD, GRigOletTi JUNIOR A, Auer CG AND Miguel OG. 2007. Phytochemical and antibacterial evaluation of essential oils from Ottonia martiana Miq. (Piperaceae). J Braz Chem Soc 18: 184188.

Cunico MM, Miguel OG, Miguel MD, Carvalho Jls, MONTRUCCHIO DP, FERREIRA JL AND OLIVEIRA JS. 2003. Extraction of sterols in fruits of Ottonia martiana Miq., Piperaceae, with liquefied gas. Quim Nova 26: 803806.

DENIZOT F AND LANG R. 1986. Rapid colorimetric assay for cell growth and survival. Modifications to the tetrazolium dye procedure giving improved sensitivity and reliability. J Immun Methods 89: 271-277.

ELMQVIST T. 1997. Plant biodiversity-evolutionary and ecological perspectives. In: Bohlin L (Ed), Bioassay Methods in Natural product research and drug Development. Sweden: Kluwer Academic Publishers, p. 1-9.

Ghelardini C, Galeotti N, Di Cesare Mannelli L, MAZZANTI G AND BARTOLINI A. 2001. Local anaesthetic activity of beta-caryophyllene. Farmaco 56: 387-389.

Giesbrecht AM, Alvarenga MA, GotTlieb OR AND GOTTLIEB HR. 1981. (2E,4E)-N-isobutyl-9-piperonylnona-2,4-dienoic amide from Ottonia anisum. Planta Med 43: 375-377.

GROPPO FC, RAMACCIATO JC, SIMÕES RP, FLÓRIO FM AND SARTORATTO A. 2002. Antimicrobial activity of garlic, tea tree oil, and chlorhexidine against oral microorganisms. Int Dent J 52: 433-437.

Guimarães EF, ICHASo CLF AND Costa CG. 1978. Piperáceas. 1. Ottonia. 2. Sarcorachis. 3. Potomorphe. In: Reitz PR (Ed), Flora Ilustrada Catarinense, Itajai: CNPq/ IBDF/HBR, Parte I, p. 3-26.

KINGHORN AD AND BALANDRIN MF. 1993. Human medicinal agents from plants. Washington, DC, ACS Symposium Series 534: 1-356.

LITCHFIELD JT AND WILCOXON FA. 1949. A simplified method of evaluating dose-effect experiments. J Pharmacol Exp Ther 96: 99-113.
MAKAPUGAY HC, SOEJARTO DD, KinghorN AD AND BORDAS E. 1983. Piperovatine, the tongue-numbing principle of Ottonia frutescens. J Ethnopharmacol 7: 235238.

MCFERREN MA, CORDOVA D, RODRIGUEZ E AND RAUH JJ. 2002. In vitro neuropharmacological evaluation of piperovatine, an isobutylamide from Piper piscatorum (Piperaceae). J Ethnopharmacol 83: 201-207.

MCFERREN MA AND RodRIGUEZ E. 1998. Piscicidal properties of piperovatine from Piper piscatorum (Piperaceae). J Ethnopharmacol 60: 183-187.

Palomino JC, Martin A, CAMACho M, Guerra H, SWINGS J AND PORTAELS F. 2002. Resazurin microtiter assay plate: simple and inexpensive method for detection of drug resistance in Mycobacterium tuberculosis. Antimicrob Agents Chemother 46: 2720-2722.

PRICE SJ AND PINDER AR. 1970. Chemistry of Ottonia vahlii. II. Constitution of the nonvolatile component. J Org Chem 35: 2568-2571.

PRING BG. 1982. Isolation and identification of amides from Piper callosum. synthesis of pipercallosine and pipercallosidine. J Chem Soc Perkin Trans 1: 1493-1498.

RANG H, DALE M, RitTER J AND GARDNER P. 2001. Pharmacology. Churchill Livinstone, Philadelphia, USA, $839 \mathrm{p}$.

RATes SMK, Chaves CG AND VON POSSER GL. 1997. Investigation of local anesthetic effect and toxicity of Ottonia propinqua (Piperaceae). Acta Farm Bonaerense 16: 113-116.

SÁez J, Granados H, Escobar G, CARdona W, ATEhortua L, CALlejas R, CORTES D AND GONZALEZ C. 1998. Piperlonguminina y estigmasterol, compuestos de raíces y tallos de Piper auritum, actividad insecticida de extractos. Rev Colomb Quim 27: 77-81.

SAKURADA T, KATSUMATA K, TAN-NO K, SAKURADA S AND KISARA K. 1992. The capsaicin test in mice for evaluating tachykinin antagonists in the spinal cord. Neuropharmacology 31: 1279-1285.

SARAC N AND UGUR A. 2007. Antimicrobial activities and usage in folkloric medicine of some Lamiaceae species growing in Mugla, Turkey. Eur Asia J Bio Sci 1: 28-34.

SOUZA MM, BELLA CRUZ A, SCHUHMACHER MB, KREUGER MRO, FREITAS RA AND BELlA CRUZ RC. 2003. Métodos de avaliação de atividade biológica de produtos naturais e sintéticos. In: Bresolin TMB and Cechinel Filho V (Org), Ciências Farmacêuticas: Contribuição ao desenvolvimento de novos fármacos e medicamentos. Itajaí; Ed. Univali. p. 108-166.

VOGEL HG. 2002. Cough induced by mechanical stimulation. In: Vogel HG (Ed), Drug discovery and evaluationpharmacological assays. Berlin: Springer-Verlag, p. 374375. 
WHO - World HeAlth ORganization. 2002. General guidelines for methodologies on research and evaluation of traditional medicine. World Health Organization Geneva, $74 \mathrm{p}$.
WILKINSON JA, WAHLQVIST MI AND CLARK J. 2002. New food and pharmaceutical products from agriculture. RIRDC Publication n. 02/215. Kingston: Rural Industries Research and Development Corporation, $32 \mathrm{p}$. 